\title{
REVIEW OF INSULIN THERAPY IN TYPE 2 DIABETES MELLITUS AMBULATORY PATIENTS
}

\begin{abstract}
Budi Suprapti ${ }^{1,3 *}$, Nia Widyasari ${ }^{1}$, Mahardian Rahmadi ${ }^{1,3}$, Cahyo Wibisono ${ }^{2,3}$
${ }^{1}$ Faculty of Pharmacy

Universitas Airlangga, Jl.

Dharmawangsa No 4-6,

Surabaya, Indonesia

${ }^{2}$ Faculty of Medicine

Universitas Airlangga, Jalan

Dr. Moestopo, Surabaya,

Indoensia

3Universitas Airlangga

Teaching Hospital, Jalan

Mulyorejo, Surabaya,

Indonesia

Submitted: $11-11-2017$

Revised: 25-11-2017

Accepted: 20-12-2017

*Corresponding author

Budi Suprapti

Email:

ABSTRACT

The purposes of this study were to review utilization of insulin therapy in type 2 diabetes mellitus out patients and identify its Drug Related Problems (DRP). The data were collected crosssectionally with purposive sampling method in the period March 2016 until May 2016 in Outpatient Clinic of Teaching Hospital Universitas Airlangga Surabaya. The results of 240 patients showed that insulin was used as monotherapy (insulin) in $2.9 \%$ patients; combination 1 insulin \& 1-4 OAD in 31.3\%; basal bolus therapy 27.9\%; combination basal-bolus therapy \& 1-3 OAD $43.9 \%$. Based on blood glucose target achievement, only $20.8 \%$ of patients achieve the target, $75.1 \%$ failed to achieve the target and $4.1 \%$ suffered from hypoglycemia. DRP identified adverse drug reaction of antidiabetic therapy such as hypoglycemia $(6.7 \%)$, nausea $(3.8 \%)$, bloating $(1.3 \%)$, increase of flatulency $(2.9 \%)$ and inappropriate combination $(0.4 \%)$ were observed. In conclusion insulin therapy was complicated and individually, most of the patients still did not achieve the target and there was potential DRP in this patients group. Therefore caring from solid inter-professional health collaboration is needed.
\end{abstract}

buidprapti@yahoo.co.id
Key words: Diabetes mellitus, insulin, ambulatory patient, DRP

\section{INTRODUCTION}

Diabetes Mellitus (DM) is one of the major worldwide health problems, the incidence of DM has exhibited epidemic conditions (Barret et al., 2012). Global study data showed that DM patients in 2013 has reached 382 million people and is estimated the increase to 592 million by 2035. In 2012, 5.1 million people in the age of 20 to 79 died of diabetes, which is equivalent to one death every six seconds is caused by diabetes and nearly half $(48 \%)$ of them are under 60 years old (IDF, 2013). In 2013, diabetic patients in Indonesia had reached 8.5 million people (IDF, 2013), whereas in East Java, it was estimated up to $2.1 \%$ (RIKESDAS, 2013).

Type 2 DM requires intensive therapy management to prevent its progressivity and complications. The principal of management therapy in Type 2 DM included non-drug therapy-healthy lifestyle and drug therapy i.e. oral antidiabetic (OAD) either single or in combination with insulin (Suastika et al., 2011). When blood glucose levels remain uncontrolled, the OAD administration is stopped and the therapy is switched to insulin intensively (Ndraha, 2014). Early initiation of insulin therapy shows better clinical outcomes primarily related to glucotoxicity (Suastika et al., 2011). In addition, according to a study by UKPDS 35, the early insulin therapy in Type 2 DM intensively showed a decrease in morbidity or mortality (Soewondo et al, 2010).

Initiation of insulin therapy in patients with type 2 diabetes could be conducted in patients who fail oral antidiabetic therapy (OAD), has poor blood glucose control (A1C> $7.5 \%$ or fasting blood glucose $>250 \mathrm{mg} / \mathrm{dL}$ ), with history of pancreatomy or pancreatic dysfunction, history of fluctuations in blood glucose levels, history of ketoacidosis, and experienced of DM over 10 years (Rismayanthi, 2010). In addition, insulin therapy is also given to patients with type $2 \mathrm{DM}$ who have some comorbid such as chronic hepatitis, pulmonary tuberculosis, fractures, cancer, cellulitis/ gangrene, graves' disease and severe hepatic disorders (Pranoto, 2012). This study aims to review the use of insulin therapy in type $2 \mathrm{DM}$ patients and identification of drug-related problems in these patients. 


\section{MATERIAL AND METHODS}

This is an observational and crosssectional study conducted at the Out-patient Clinic Universitas Airlangga Teaching Hospital in Surabaya, Indonesia. Inclusion criteria were Type $2 \mathrm{DM}$ patients undergoing therapy using insulin or insulin-OAD (Oral Anti Diabetic) combination. The data were collected from March to May 2016. The sampling was obtained by purposive sampling method until the sample number was fulfilling. Descriptive analysis was conducted for the patient's insulin therapy profile, achievement of blood sugar target and problems that are related to antidiabetic.

\section{RESULT AND DISCUSSION}

From 240 patients obtained there were $127(52.9 \%)$ female patients which was higher than male patients, 113 (47.1\%). This aligned with the International Diabetes Federation data that shows the prevalence of DM patients in Indonesia is higher in women, that is $57.73 \%$ (IDF, 2013). The higher prevalence of Type 2 DM patients in women is associated with lower physical activity and more obesity conditions experienced by women (WHO, 2016).

Based on age distribution, it shows that more patients in the age of the 45-54 years there were $(25.8 \%)$ and $55-64$ years $(41.2 \%)$ (Table I). This is in accordance with the research conducted by the Center for Disease Control and Prevention, which shows that most people with Type $2 \mathrm{DM}$ are in the age range of 45-64 years (CDC, 2015), where at age $>45$ years the insulin resistance increase and impaired function of pancreatic cells (Kyung et al., 2016). The impaired of pancreatic cell function causes a decrease in the capacity of proliferative islet cells resulting in a decrease in insulin production (Kirkman et al., 2012). However, in this study there were $7.5 \%$ of patients in the age of $<45$ years and there was one patient $(0.4 \%)$ at the age of 25 years old. Research conducted by the Ministry of Health of the Republic of Indonesia in 2013 showed that $9.90 \%$ of patients with Type $2 \mathrm{DM}$ is at the age $<45$ years (RISKESDAS, 2013). This indicates that incidence of Type $2 \mathrm{DM}$ is increasing among young people. Lifestyle and obesity is the main factors suspected to be the cause of Type 2 DM. In addition, genetic factors, gestational diabetes and lack of physical activity during childhood and adolescence lead to an increase in insulin resistance that triggers the onset of Type $2 \mathrm{DM}$ among young people (Bloomgarden, 2004).

In Type 2 DM patients may be accompanied by various microvascular and macrovascular and comorbid complications (Table I). In this study the most complication experienced was nephropathy $24.2 \%$ and comorbid was hypertension 62.9\%. Diabetic nephropathy is a microvascular complication characterized by hyperfiltration of the glomerular basement membrane (Funk, 2014). The pathogenesis of diabetic nephropathy may be an increase in AGEs product that causes damage to the renal glomerulus. In addition, polyol pathway increases sorbitol and decreases inositol levels causing impaired basement membrane osmolarity (Bennett and Bhardari, 2015). While, in this study $62.9 \%$ patients with hypertension. Hypertension is a risk factor for DM (ADA, 2015), in the other hand hypertension is one complication of DM. A hyperglycemia conditions cause glucose to react non-enzymatically with free amino acids of the body membrane, produce AGEs product that will cause damage the organs and blood vessel network as well as the formation of arteriosclerosis that causes narrowing of artery walls (Funk, 2014).

According to PERKENI, at the beginning of therapy Type $2 \mathrm{DM}$ can be used OAD monotherapy. If blood glucose has not been controlled with OAD monotherapy use a combination of 2 OAD with a different mechanism. If on 2 OAD combinations blood glucose still uncontrollable a combination of 3 $\mathrm{OAD}$ or a combination of $2 \mathrm{OAD}$ can be used together with basal insulin. If on this combination blood glucose remains uncontrolled, then the OAD is stopped and the therapy switches to insulin intensively (PERKENI, 2011). The European Association for the Study of Diabetes (EASD) recommends the more aggressive type $2 \mathrm{DM}$ therapy that after the first step with lifestyle intervention and metformin is unsuccessful, the next step can be started by administering insulin. Early insulin initiation provides better glycemic 
Budi Suprapti

Tabel I. Characteristic of Type 2 DM Patients in Out Patients Clinic Universitas Airlangga Teaching Hospital Surabaya Indonesia

\begin{tabular}{|c|c|c|c|}
\hline No. & & Characteristic & Number of patients (\%) \\
\hline \multirow[t]{2}{*}{1} & Gender & Male & $113(47,1)$ \\
\hline & & Female & $127(52.9)$ \\
\hline \multirow[t]{6}{*}{2} & Age (year) & $25-34$ & $1(0.4)$ \\
\hline & & $35-44$ & $18(7.7)$ \\
\hline & & $45-54$ & $62(25.8)$ \\
\hline & & $55-64$ & $99(41.2)$ \\
\hline & & $65-74$ & $46(19.2)$ \\
\hline & & $>75$ & $14(5.8)$ \\
\hline \multirow[t]{8}{*}{3} & Complication & Nephropathy & $58(24.2)$ \\
\hline & & Neuropathy & $20(8.3)$ \\
\hline & & Retinopathy & $1(0.4)$ \\
\hline & & Coronary Artery Disease & $5(2.1)$ \\
\hline & & Stroke & $4(1.7)$ \\
\hline & & Ulcus Pedis & $2(0.8)$ \\
\hline & & Gangrene & $2(0.8)$ \\
\hline & & Chronic Kidney Disease & $4(1.7)$ \\
\hline \multirow[t]{17}{*}{4} & Comorbid & Hypertension* & $151(62.9)$ \\
\hline & & Dyslipidemia & $102(42.5)$ \\
\hline & & Dyspepsia & $16(6.7)$ \\
\hline & & Hypertoroid & $1(0.4)$ \\
\hline & & Hyperuricemia & $31(12.9)$ \\
\hline & & Osteoarthritis & $9(3.7)$ \\
\hline & & Heart failure & $3(1.2)$ \\
\hline & & Hepatic Cirrhosis & $1(0.4)$ \\
\hline & & Ascites & $1(0.4)$ \\
\hline & & Frozen shoulder & $1(0.4)$ \\
\hline & & Acute Respiratory infection & $5(2.1)$ \\
\hline & & Anemia & $1(0.4)$ \\
\hline & & Cholelithiasis (Batu empedu) & $4(1.7)$ \\
\hline & & Low Back Pain (LBP) & $1(0.4)$ \\
\hline & & Benign Prostate Hyperplasia (BPH) & $3(1 . .2)$ \\
\hline & & Asthma & $2(.8)$ \\
\hline & & Vertigo, Cephalgia & $3(1.2)$ \\
\hline
\end{tabular}

Note:, A patient could have more than one complication and comorbid; Percentage to total patient (240 patient); $\left({ }^{*}\right)$ Hypertension not known it is DM complication or comorbid. So in this study HT classified into comorbid.

control, improves HbA1C and inhibits the progressivity of decreased pancreatic $\beta$ cell function (Meneghini, 2009; Inzucchi et al., 2015). In addition, according to a study by UKPDS 35 , the use of early insulin therapy in Type 2 DM intensively showed decreased morbidity or mortality (Soewondo et al, 2010). The profiles of antidiabetic, insulin and OAD use were shown in Figure 1, single insulin therapy $(2.9 \%)$, a combination of 1 insulin and
OAD (31.3\%), basal-bolus combination $(27.9 \%)$, and combination basal bolus insulinOAD $(37.9 \%)$.

The types of antidiabetic used were rapid-acting insulin (aspart, glulisine), longacting insulin (glargine, determir) and mixed insulin (70/30 protamine aspart/aspart and $75 / 25$ protamine lispro/lispro) subcutaneously, and sulfonylureas, biguanides, thiazolidinedione and a-glucosidase inhibitors orally (Table II). 


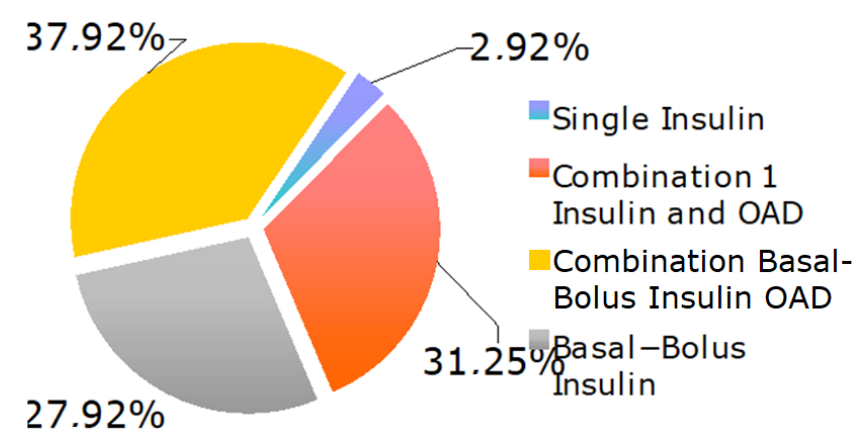

Figure 1. Profile of antidiabetic therapy in out patients clinic universitas

Tabel II. Type of antidiabetes used in in out patients clinic Universitas Airlangga Teaching Hospital Surabaya Iherapy

\begin{tabular}{llrr}
\hline \multicolumn{1}{c}{ Class } & Name & Frequency & $\begin{array}{r}\text { Total patients in } \\
\text { each class (\%) }\end{array}$ \\
\hline Insulin & & & \\
Rapid-acting & Aspart & $81(33.75)$ & $100(41.7)$ \\
& Glulisine & $19(7.92)$ & \\
Long-acting & Glargine & $105(43.75)$ & $174(72.5)$ \\
& Detemir & $69(28.75)$ & \\
Mixed & $-70 / 30$ Protamine Aspart/ Aspart & $58(24.17)$ & $62(25.8)$ \\
& - 75/25 Protamine Lispro/ Lispro & $4(1.67)$ & \\
OAD & Metformin & $102(42.50)$ & $102(42.5)$ \\
Biguanida & Glimepirid & $70(29.17)$ & $89(37.1)$ \\
Sulfonilurea & Gliclazid & $10(4.17)$ & $17(7.1)$ \\
& Glikuidon & $9(3.75)$ & 49 \\
Tiazolidinedione & Pioglitazone & $17(7.08)$ & $(20.4)$ \\
a-glukosidase & Acarbose & $4920.42)$ & \\
inhibitor & & & \\
\hline
\end{tabular}

Note : A Patients could get more than one antidiabetes; Percentage to tatal patient (240 patient)

Long-acting insulin is most widely used, $72.50 \%$ of the total patient. The use of longacting insulin in patients with Type $2 \mathrm{DM}$ is to cover basal insulin needs (Schwinghammer, 2015). The most widely used long-acting insulin is glargine, $43.75 \%$, an insulin analog that has a long acting and peakless. Insulin glargine has a slow onset of action (1-1.5h) and give maximum effect after 4-6h, the activity is maintained for 11-24h or more. Insulin glargine is a clear liquid insulin with a $\mathrm{pH}$ of 4 , after subcutaneous injection will form micro- precipitation in so that release slowly (Schwinghammer, 2015).
Another long-acting insulin applied is detemir. Detemir insulin has an onset of action 1-2h and a duration of action about 24h (Kennedy and Masharani, 2015). In detemir insulin, the C14 fatty acids are bound to albumin, causes slow release (Schwinghammer, 2015). Administration long-acting insulin can be given in the morning or evening. In this study long-acting insulin $79.89 \%$ was administered at night. The use of basal insulin at night can significantly reduce the production of basal glucose hepar in order to provide better glycemic control (Pranoto, 2012). 
Budi Suprapti

Table III. Dose and frequency of insulin administration

\begin{tabular}{|c|c|c|}
\hline Drug Name & Insulin Dose & Frequency \\
\hline Aspart & $4-26 \mathrm{U}$ & $3 x$ \\
\hline Glulisine & $5-32 \mathrm{U}$ & $3 x$ \\
\hline Glargine & $6-50 \mathrm{U}$ & $1 \mathrm{x}$ \\
\hline Detemir & $6-44 \mathrm{U}$ & $1 \mathrm{x}$ \\
\hline 70/30 Protamine Acnart/Asnort & $(6-30)-0-(6-28) \mathrm{U}$ & $2 \mathrm{x}$ \\
\hline /0/30 Protamine Aspart/ Aspart & $(30-34)-10-(28-30) \mathrm{U}$ & $3 x$ \\
\hline 75/25 Protamine Lispro/Lispro & $(12-24)-0-(10-20) \mathrm{U}$ & $2 \mathrm{x}$ \\
\hline
\end{tabular}

Table IV. Time administration of long acting insulin

\begin{tabular}{ccc}
\hline \multirow{2}{*}{ Type of Long Acting Insulin } & \multicolumn{2}{c}{ Time of Administration } \\
\cline { 2 - 3 } & Morning (\%) & Night (\%) \\
\hline Glargine & 19 & 86 \\
Detemir & 16 & 53 \\
Total & $35(20.1)$ & $139(79.9)$ \\
\hline
\end{tabular}

Note: Percentage of total patient who is got glargine or detemir (174 patient)

From 240 patients, 41.7\% received rapid insulin therapy. The administration of rapidacting insulin aims to fulfill insulin needs at mealtime, because it has a shorter onset and shorter duration of action that mimics normal endogenous insulin secretion (Kennedy and Masharani, 2015). The most widely used type of rapid-acting insulin was aspart insulin 33.8\%. Aspart insulin is an insulin analogous with the replacement of the B28 amino acid structure with aspartic acid (Tanyolac et al., 2010). This structural change causes rapid dissociation into monomer form when injected subcutaneously. The onset of action of insulin aspart is $5-15 \mathrm{~min}$ with a duration of action of 4-6h. Other rapid-acting insulin used is glulisine insulin $7.9 \%$. Glulisine insulin is an analogue insulin that replaces B3- amino acid asparagin with lysine and lysine at the B29 position is replaced with glutamic acid. The onset of action glulisine insulin is $15 \mathrm{~min}$ with a duration of action about 5h (Tanwani, 2011).

Mixed insulin (premixed insulin) contains long-acting insulin and rapid-acting insulin with a certain ratio in a dosage. The advantage of mixed insulin has a prandial and basal glycemic effect at once, thus it can provide longer glycemic control (Pranoto, 2012). Type of mixed insulin used was $70 / 30$
Protamine Aspart/Aspart insulin (24.2\%) and 75/25 Protamine Lispro/Lispro insulin (1.7\%). Onset of action 70/30 Protamine Aspart/ Aspart insulin is $10-20 \mathrm{~min}$ with a duration of action 15-18h.

According to the American Diabetes Association, the use of insulin in type 2 diabetes can be started with long-acting insulin in the morning or before bedtime with an initial dose of $10 \mathrm{U}$ or $0.2 \mathrm{U} / \mathrm{kgBW}$ (ADA, 2015). Titration was performed base on blood glucose monitoring, by increasing $2 \mathrm{U}$ doses every 3 days until fasting blood glucose (FBG) reaches $(70-130 \mathrm{mg} / \mathrm{dL})$, or it can be increased $4 \mathrm{U}$ or more if $\mathrm{FBG}>180 \mathrm{mg} / \mathrm{dL}$. If there is a hypoglycemia or FBG $<70 \mathrm{mg} / \mathrm{dL}$, dose decreased by $2-4 \mathrm{U}$. The addition of rapidacting insulin may be performed if $2 \mathrm{~h}$ postprandial blood glucose (2PPBG) is high, the initial dose usually begins with $4 \mathrm{U}$ and adjusts $2 \mathrm{U}$ every 3 days until blood glucose is within the target range (Nathan, 2009).

The dosage and frequency of insulin (Table III). In this study, the dose of long-acting insulin in the range 6- 50 units and rapid-acting insulin 4-32 units, while the mixed insulin dose is between 6-34 units in the morning and 6-30 units at night. 
Table V. Use of Insulin and Insulin-OAD Combination

\begin{tabular}{|c|c|c|}
\hline Type of Regimen & Agent & Number of Patients (\%) \\
\hline \multirow{4}{*}{ Single Insulin } & Rapid acting insulin & $1(0.4)$ \\
\hline & Long acting insulin & $6(2.5)$ \\
\hline & Total & $7(2.9)$ \\
\hline & Long acting insulin $+\mathrm{SU}$ & $26(10.7)$ \\
\hline \multirow{3}{*}{$\begin{array}{l}\text { Type } 1 \text { combination } \\
\text { (1 Insulin }+1 \text { OAD) }\end{array}$} & Long acting insulin + Big & $1(0.4)$ \\
\hline & Rapid acting insulin $+\mathrm{SU}$ & $2(0.8)$ \\
\hline & Total & 29 (12.1) \\
\hline \multirow{5}{*}{$\begin{array}{l}\text { Type } 2 \text { combination } \\
\text { (1 Insulin }+2 \text { OAD })\end{array}$} & Long act. Insulin+ AGI+SU & $7(2.9)$ \\
\hline & Long act. Insulin $+\mathrm{Big}+\mathrm{SU}$ & $22(9.2)$ \\
\hline & Long act. Insulin +TZD + SU & $3(1.2)$ \\
\hline & Rapid act. Insulin + Big + SU & $1(0.4)$ \\
\hline & Total & 33 (13.7) \\
\hline \multirow{3}{*}{$\begin{array}{l}\text { Type } 3 \text { combination } \\
\text { (1 Insulin + } 3 \text { OAD) }\end{array}$} & Long act. insulin $+\mathrm{AGI}+\mathrm{SU}+\mathrm{Big}$ & $11(4.6)$ \\
\hline & Long act. insulin $+\mathrm{SU}+\mathrm{Big}+\mathrm{TZD}$ & $1(0.4)$ \\
\hline & Total & $12(5.0)$ \\
\hline \multirow{6}{*}{$\begin{array}{l}\text { Type } 4 \text { combination } \\
\text { (1 Insulin }+4 \text { OAD) } \\
\text { Type } 5 \text { combination } \\
\text { (Insulin Basal-Bolus) }\end{array}$} & Long act. Insulin + AGI + SU + Big + TZD & $1(0.4)$ \\
\hline & Total & $1(0.4)$ \\
\hline & Rapid act. Insulin + Long act.insulin & $46(19.2)$ \\
\hline & $70 / 30 \mathrm{mix}$ insulin & $19(7.9)$ \\
\hline & $75 / 25$ mix insulin & $2(0.8)$ \\
\hline & Total & $67(27.9)$ \\
\hline \multirow{9}{*}{$\begin{array}{l}\text { Type } 6 \text { combination } \\
\text { (Insulin Basal-Bolus } \\
+1 \text { OAD) }\end{array}$} & Rapid act. Insulin + long act. Insulin + AGI & $5(2.1)$ \\
\hline & Rapid act. Insulin + long act. Insulin + Big & $14(5.8)$ \\
\hline & Rapid act. Insulin + long act. Insulin + TZD & $5(2.1)$ \\
\hline & 70/30 Mix insulin + AGI & $8(3.3)$ \\
\hline & 70/30 Mix insulin + SU & $2(0.8)$ \\
\hline & 70/30 Mix insulin + Big & $13(5.4)$ \\
\hline & 70/30 Mix insulin + TZD & $3(1.2)$ \\
\hline & 75/25 Mix insulin + Big & $1(0.4)$ \\
\hline & Total & $61(25.42)$ \\
\hline \multirow{11}{*}{$\begin{array}{l}\text { Type } 7 \text { combination } \\
\text { (Insulin Basal-Bolus } \\
+2 \mathrm{OAD} \text { ) }\end{array}$} & Rapid act. Insulin + long act. Insulin + AGI + Big & $7(2.9)$ \\
\hline & Rapid act. Insulin + long act. Insulin $+\mathrm{SU}+\mathrm{Big}$ & $10(4.2)$ \\
\hline & Rapid act. Insulin + long act. Insulin + Big + TZD & $1(0.4)$ \\
\hline & Rapid act. Insulin + long act. Insulin + AGI + SU & $1(0.4)$ \\
\hline & Rapid act. Insulin + long act. Insulin + AGI + TZD & $1(0.4)$ \\
\hline & 70/30 Mix Insulin + AGI + Big & $1(0.4)$ \\
\hline & 70/30 Mix Insulin + AGI + SU & $4(1.7)$ \\
\hline & 70/30 Mix Insulin + SU + Big & $2(0.8)$ \\
\hline & 70/30 Mix Insulin + Big + TZD & $1(0.4)$ \\
\hline & $75 / 25$ Mix Insulin + SU + Big & $1(0.4)$ \\
\hline & Total & $29(12.1)$ \\
\hline \multirow{3}{*}{$\begin{array}{l}\text { Type } 8 \text { combination } \\
\text { (Insulin Basal-Bolus } \\
+ \\
3 \text { OAD) }\end{array}$} & $\begin{array}{l}\text { Rapid act. Insulin+long act. } \\
\text { Insulin+AGI+Big+TZD }\end{array}$ & $1(0.4)$ \\
\hline & Total & $1(0.4)$ \\
\hline & Total & $240(100.0)$ \\
\hline
\end{tabular}

Note: Percentage to total patients (240 patient)

SU: sulphonyl urea (Glimepiride, Gliclazide, Gliquidone), AGI: alpha glycosidase inhibitor (acarbose), Big: biguanide (metformin), TZD: Thiazolidindione (pioglitazon), Long act. Insulin (glargin, detemir), Rapid act. Insulin (aspart, glulisine), 70/30 Mix insulin (Protamin aspart/aspart), 75/25 Mix insulin (Protamin lispro/lispro) 
Tabel VII. Post prandial blood glucose (2PPBG) and bolusi insulin adjustment (Rapid acting Insulin)

\begin{tabular}{ccrc}
\hline 2PPBG(mg/dL) & Dose Adjustment & Number of Patients (\%) & Total Patients (\%) \\
\hline \multirow{2}{*}{$<100$} & Dose reduce & $1(1.10)$ & $3(3.3)$ \\
& No change & $2(2.20)$ & \\
\multirow{2}{*}{$100-199$} & No change & $26(28.57)$ & $32(35.2)$ \\
& Dose reduce & $6(1.10)$ & \\
\multirow{2}{*}{$200-299$} & Dose reduce & $1(1.10)$ & $34(37.4)$ \\
& No Change & $20(21.98)$ & \\
$300-399$ & Dose Increase & $13(7.69)$ & $15(16.5)$ \\
& No Change & $7(7.69)$ & \\
$400-499$ & Dose increase & $8(3.30)$ & $5(5.5)$ \\
$500-599$ & No change & $1(1.10)$ & $2(2.2)$ \\
\hline
\end{tabular}

Note: Total patient $=91$ with 2 PPBG

Tabel VIII. Blood glucose achievement

\begin{tabular}{|c|c|c|c|}
\hline & Blood Glucose Level* & Number of Patients & Total $(\%)$ \\
\hline & 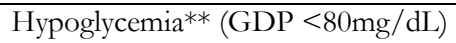 & 9 & $9(4.1)$ \\
\hline \multirow[t]{2}{*}{ Achieved the target } & - FBG 80-130mg/dL & & \\
\hline & $\begin{array}{l}\text { - } 2 \mathrm{PPBG}<180 \mathrm{mg} / \mathrm{dL} \\
\text { - } \mathrm{RBG}<200 \mathrm{mg} / \mathrm{Dl}\end{array}$ & 46 & $46(20.8)$ \\
\hline \multirow[t]{2}{*}{ Not Achieved the Target } & $-F B G>130 \mathrm{mg} / \mathrm{dL}$ & & \\
\hline & $\begin{array}{l}\text { - } 2 \mathrm{PPBG}>180 \mathrm{mg} / \mathrm{dL} \\
\text { - } \mathrm{RBG} \geq 200 \mathrm{mg} / \mathrm{dL}\end{array}$ & 110 & \\
\hline \multirow[t]{2}{*}{ FBG achieved } & - FBG 80-130mg/dL & & \\
\hline & $\begin{array}{l}\text { - } 2 \text { PP BG Not Achieved } \\
\text { - } 2 \text { PPBG }>180 \mathrm{mg} / \mathrm{dL}\end{array}$ & 37 & $166(75.1)$ \\
\hline \multirow[t]{3}{*}{ FBG Not Achieved } & $-\mathrm{FBG}>130 \mathrm{mg} / \mathrm{dL}$ & & \\
\hline & $\begin{array}{l}\text { - } 2 \text { PPBG Achieved } \\
\text { - } 2 \text { PPBG <180mg/dL }\end{array}$ & 19 & \\
\hline & Total & 221 & $(100.00)$ \\
\hline
\end{tabular}

Note: BG achievement was outcome of achievement one month therapy before; Total patient 221, there is no BG data in 19 patient; (*) ADA, 2015; (**) Hypoglycemia is indicated by FBG $<80 \mathrm{mg} / \mathrm{dL}$ (PERMENKES No. 5 Tahun 2014).

It can be seen that the dose of insulin therapy is highly individual, due to the sensitivity of insulin receptors in each individual is different, the varying action of insulin in each individual (Boucher et al., 2014).

The oral antidiabetic $(\mathrm{OAD})$ used in this study were sulfonylureas (gliclazides, glimepirides, gliquidones), biguanides (metformin), $\alpha$-glucosidase (acarbose) and thiazolidinedione (pioglitazone) inhibitors. In this study, $37.1 \%$ of patients received sulfonylurea therapy, i.e. glimepiride $(29.2 \%)$, gliclazide $(4.2 \%)$, and gliquidone $(3.8 \%)$. The
UKPDS study showed that more than 50\% of DM patients receiving sulfonylurea therapy required additional insulin therapy to achieve the glycemic target (Massi and Orsini, 2008). The combination of glimepiride with insulin can lower uncontrolled blood glucose levels (Funk, 2014). However, in the combination of insulin and sulfonylurea, patient's blood glucose levels should be monitored, considering that both drugs are synergistic in lowering blood glucose levels, which can increase the risk of hypoglycemia (Raccah et al., 2007). 
In this study, $42.5 \%$ of patients received metformin therapy. Metformin is recommended as first-line therapy for Type 2 diabetes, because it increases insulin sensitivity and not increase weight or cause hypoglycemia. Beside that metformin has lowering effect on cholesterol, free fatty acids and triglycerides, so that improved lipid profiles and inhibit the occurrence of macrovascular and microvascular complications (Hundal and Inzucchi, 2003), but this drug is contraindicated in patients with renal impairment, liver disease, hypoxia, and a history of lactic acidosis (Kroon and Williams, 2013). A total of $20.4 \%$ of patients received acarbose, an oral antidiabetic that acts by inhibiting the aglucosidase enzyme found in the small intestine wall, reduces postprandial glucose levels in Type 2 DM patients (Schwinghammer, 2015). This drug has a low risk of hypoglycemia ( $\mathrm{Li}$ Feng-fei et al., 2015). A total of 7.1\% of patients received pioglitazone, that has effect in lowering insulin resistance by increasing the amount of glucose transporter. In patients with type 2 DM with dyslipidemia, a thiazolidinedione can improve lipid profile. Research conducted by Ghazzi showed that thiazolidinedione (pioglitazone) decrease triglyceride levels and increase HDL levels in Type 2 DM patients. However, the influence of thiazolidinedione on lipids is not enough to replace statins as dyslipidemia therapy (Ismail, 2004).

Several studies have shown that intensive glycemic control can be achieved by combination therapy (Massi and Orsini, 2008). It has been stated that combination of insulin and OAD results better in glycemic control compared to single insulin use (Pranoto, 2011). The advantage of this combination can reduce the required dose of insulin, decrease the number of injections, ease insulin dose titration and improve adherence (Massi and Orsini, 2008).

In this study, $30.8 \%$ of patients received insulin therapy (single or basal-bolus) and $69.2 \%$ of patients receiving OAD-insulin combination therapy. The combination of insulin-OAD therapy is very diverse, ranging from a combination of 1-2 of insulin types and 1-4 of oral antidiabetic (Table 5). Basal-bolus therapy is given when blood glucose and HbA1C levels were still uncontrolled with combination therapy of basal insulin and OAD (Harper et al., 2013), the addition of prandial insulin improves overall glycemic control (Umpierrez et al., 2007). Prandial insulin is given at an initial dose of $6 \mathrm{U}$ or $0.1 / \mathrm{kgBW}$ and administered before each meal.

In this study, it was found that several inappropriate combinations of therapy were not in accordance with the protocol, such as the combination of rapid-acting insulin (bolus insulin) with sulfonylurea groups, which may increase the risk of hypoglycemia. Oral insulin secretagogin (sulfonylurea) should be discontinued if prandial insulin is given (Raccah et al., 2007; Pranoto, 2012). In addition, there was an inappropriate combination of longacting insulin with 4 types of oral antidiabetic (Type 4 Combination). This combination was not appropriate. According to PERKENI, if the patients receive the combination therapy of basal insulin and OAD but the blood glucose is still uncontrolled, then the therapy has to stop and shift to insulin intensively (basal-bolus therapy) (PERKENI, 2011). It is in line with the recommendation of the American Diabetes Association, if the patient's HbA1C target is not achieved for 3 months with triple therapy or combination of basal insulin and $2 \mathrm{OAD}$, it is recommended to switch to basal-bolus therapy (ADA, 2015).

The dosage and frequency of antidiabetic use in type 2 diabetes mellitus therapy are highly dependent on patient's condition that includes blood glucose level, HbA1C value, complication and comorbid, and patient compliance. Blood glucose levels (FBG and 2PPBG) are indicators of patient glycemic level controls. Dose adjustment of long-acting insulin was based on FBG, while rapid-acting insulin dose is adjusted to 2PPBG (ADA, 2015). In Table VI showed the value patient's fasting blood glucose (FBG) levels and its basal insulin therapy. Patients with FBG $<70 \mathrm{mg} / \mathrm{dL}$ $(2.3 \%)$ had hypoglycemic conditions, so it was recommended to decrease the insulin dose by 2-4U (Nathan, 2009). Patients with FBG 70$130 \mathrm{mg} / \mathrm{dL}(37.8 \%)$ is recommended to maintain the dose, but in this study there was an increase insulin dose by 2-6 U, this was due to blood glucose levels still reaches the upper limit of the glycemic target and the patient has 
a high 2PPBG level. The addition of a basal insulin dose may be lowering the patient's 2PPBG levels (Rakel et al., 2015). In some patients there was a dose reduction of 2-8 $\mathrm{U}$ because the patient has a risk of hypoglycemia or experienced hypoglycemia. Patients with GDP $>130 \mathrm{mg} / \mathrm{dL}(30 \%)$ and GDP $>180$ $\mathrm{mg} / \mathrm{dL}(30 \%)$ were recommended for the addition of $2-4 \mathrm{U}$ insulin, but $31.3 \%$ of patients with high GDP levels were not added insulin because there is significant BG decrease from previous therapy. The simillar reason use for insulin adjustmen 2PPBG.

Many aspects must be considered in determining the patient's glycemic target. The recommended glycemic target by the American Association Diabetes is the optimal target, but the glycemic target is individualized and tailored to the needs of each patient (ADA, 2015). Factors to be considered for the determination of glycemic targets in patients with type 2 diabetes include age or life expectancy, comorbidity, duration of diabetes, the risk of hypoglycemia, and presence of microvascular complications (ADA, 2015).

Blood glucose target is achieved if FBG is in the range $80-130 \mathrm{mg} / \mathrm{dL}$ and 2 PPBG $<180 \mathrm{mg} / \mathrm{dL}$ (ADA, 2015). This study showed of 240 patients with Type 2 DM there were 19 patients who did not have blood glucose levels at the time of observation, so that the blood glucose level was obtained from 221 patients. Of the 221 patients, $20.8 \%$ patients achieved BG target, while $75.1 \%$ patients did not achieve blood glucose target. It showed that blood glucose controled in these patients is not easy. These patients were referral patients from first health services, sent to hospital as higher second health services cause they had uncontrolled blood glucose or had DM complication. As blood glucose or complication has been controlled this patients would be referred back to first health services. Previous study in type $2 \mathrm{DM}$ geriatric patients showed blood glucose target was achieved in 53\% patients (Suprapti et al, 2014).

A total of $4.1 \%$ of patients had hypoglycemic conditions, characterized by FBG level $<80 \mathrm{mg} / \mathrm{dL}$. According to the ADA, the condition of hypoglycemia is characterized by blood glucose levels $<70 \mathrm{mg} / \mathrm{dL}$, but criteria for hypoglycemia in the clinic is characterized by blood glucose $<80 \mathrm{mg} / \mathrm{dL}$, this is done because the hypoglycemia condition is dangerous and life-threatening, so that higher values are used for the purpose of patient safety. It also complies with PERMENKES No.5, 2014 on the Clinical Practice Guidelines for Physicians, which explains that hypoglycemia is characterized by blood glucose levels $<80 \mathrm{mg} / \mathrm{dL}$ (PERMENKES RI, 2014).

Side effects of insulin found in this study were hypoglycemia. A total of $6.7 \%$ of patients had hypoglycemia and were identified to receive insulin or sulfonylurea therapy. Potential side effects of insulin and sulfonylurea use are hypoglycemia (Kennedy \& Masharani, 2015). Hypoglycemia is shown in the presence of complaints such as shaking, cold sweat, dizziness, weakness and palpitations. Patients with hypoglycemia usually result from overly high doses of insulin, inadequate dietary intake (delayed, skipped meal, little intake), fasting conditions, excessive activity. Other DRP found were an inappropriate combination, i.e. the combination of rapid-acting insulin with sulfonylurea group OAD (3.8\%), and a combination of 1 insulin with $4 \mathrm{OAD}(0,4 \%)$.

\section{CONCLUSION}

In conclusion insulin therapies were complicated and individually, most of the patients still did not reach the target and there was potential drug related problem in this patients group. So that caring from solid interprofesional health collaboration is nedeed.

\section{ACKNOWLEDGEMENT}

We are grateful to Universitas Airlangga Teaching Hospital for permission doing this research.

\section{REFERENCES}

American Diabetes Association., 2015. Standards of Medical Care in Diabetes: Volume 38 Suplement 1: S1-S83

Barret KE., Barman SM., Boitano S., Brooks HL. 2012. Ganong's Review of Medical Physiology. 24th Edition. New York: The McGraw-Hill Companies.

Bennett K., Bhandari., 2015. An overview of diabetic nephropathy: Epidemiology, pathophysiology and treatment. J Diabetes Nursing. 19: 2: 61-67 
Bloomgarden TZ., 2004. Type 2 Diabetes in the Young: The envolving epidemic. Diabetes Care. 27: 4. pp. 998

Boucher J., Kleinridders A., Kahn C. Ronald., 2014. Insulin Receptor Signaling in Normal and Insulin-Resistant States. Harvard Medical School

CDC. 2015. Distribution of Age at Diagnosis of Diabetes Among Adult Incident Cases Aged 18-79 Years. Centers for Disease Control and Prevention

Funk JL. 2014. Disorder of The Endocrine Pancreas. In: McPhee.S. J; Hammer G.D. (Eds.), Pathophysiology of Disease an Introduction to Clinical Medicine. 7th ed. : New York : Mc Graw Hill

Harper W., Clement M., Goldenberg R., Hanna A., Main A., et al., 2013. Pharmacologic Management of Type 2 Diabetes. Can. J.Diabetes. 37(2013): S61-S68

Hundal, R.S., Inzucchi, S.E., 2003. Metformin: New Understandings, New Uses. Leading Article. pp 1800-1889

IDF Diabetes Atlas. 2013. International Diabetes Federation 6th ed. pp: 19-99

Inzucchi SE., Bergenstal RM., Ferrannini E., Nauck M., Peters AL., et al., 2015. Management of Hyperglycemia in Type 2 Diabetes, 2015: A Patient Center Approach. Diabetes Care 2015; 38: 140149

Ismail F., 2004. Current Management of Type 2 Diabetes: Why Thiazolidinediones Should Be the Cornerstone of Therapy. The J. Applied Research. Volume. 4, No 3.

Kennedy and Masharani. 2012. Pancreatic Hormones and Antidiabetic Drugs. In: Basic and Clinical Pharmacology. 12th Edition. New York: The McGraw-Hill Companies, p. 743-765.

Kirkman MS., Jones VB., Clark, N., Florez H., Haas, LB., et al 2012. Diabetes in Older Adults. Diabetes Care, V35. 2650-2655

Kroon and Williams. 2013. Endocrine Disorders. In: Koda-Kimble \& Young's (Eds.). Applied Therapeutics the Clinical Use of Drugs.10th ed. Wolters Kluwer Health: Lippincott Williams \& Wilkins.

Kyung BK., Roh E., Seul YY., Kyong MM., 2016. Difference between old and young adults in contribution of $\beta$-cell function and sarcopenia in developing diabetes mellitus. Original Article: J Diabetes Investigation, Volume 7, No.2, pp 233-238

Massi MB., Orsini MF., 2008. Treatment of Type 2 Diabetes with Combined Therapy. Diabetes Care, Volume 31, Supplement 2.

Meneghini LF., 2009. Early Insulin Treatment in Type 2 Diabetes. Diabetes Care. 32:2: S266-S269

Nathan DM. Buse JB. Davidson MB., Ferrannini E. Holman RR., et al., 2009. Medical Management of Hyperglycemia in Type 2 Diabetes: A Consensus Algorithm for the initiation and Adjustment of Therapy, Vol 32. No.1. pp 193-203

Ndraha S. 2014. Medicinus : Diabetes Melitus Tipe 2 dan TataLaksana Terkini Vol 27 No.2. Jakarta

PERKENI. 2011. Konsensus Pengelolaan dan Pencegahan Diabetes Melitus Tipe 2 Di Indonesia. Pengurus Besar Perkumpulan Endokrinologi Indonesia.

Pranoto A., 2011. Insulin Therapy for Type 2 Diabetes Early Insulination: Rationale \& Evidence. Pusat Diabetes \&o amp

Pranoto A. 2012. Terapi Insulin: Pada Penderita Diabetes Melitus Rawat Jalan dan Rawat Inap. Surabaya: Airlangga University Press.

Raccah D., Bretzel RG., Owens D., Riddle M., 2007. When basal insulin therapy in type 2 diabetes mellitus is not enough-what next? Diabetes Metab Res Rev 23(4):257264

RISKESDAS., 2013. Riset Kesehatan Dasar, Jakarta: Balitbang Kementerian Kesehatan Republik Indonesia.

Rismayanthi Cerika. 2010. Medikora : Terapi Insulin Sebagai Alternatif Pengobatan Bagi Penderita Diabetes : Vol VI, No. 2. Yogyakarta

Schwinghammer TL. 2015. Endocrinologic Disorders. In: Dipiro, J. T. Pharmacotherapy: A Pathophysiologic Approach. 7th Ed.: New York, McGraw-Hill Medical. pp 155- 175.

Soewondo P., Soegondo S., Suastika K., Pranoto A., Soeatmadji D.W., Tjokroprawiro A. 2010. The DiabCare Asia 2008 study - Outcomes on control and complications of type 2 diabetic patients in Indonesia Vol.19, No 4. 
Suastika K., Soeatmadji DW., Asdie., Adam MF., Soegondo S., et al., 2011. Petunjuk Praktis Terapi Insulin. pp. 1-35

Suprapti B., Vilaningtyas N, Nilamsasri WP, Ichwani J., 2014. Lood glucose target achievement and antidiabetes regimen in Type-2 Diabetes Geriatric Patients. Indonesian J. Pharm, Vol. 25:2, pp. 98-104.

Tanwani LK. 2011. Insulin Therapy in the Elderly Patient with Diabetes. The Am J Geriatric Pharmacotherapy. Louisville, Kentucky. pp 24-33.

Tanyolac S., Goldfine, ID., Kroon L. 2010.
Insulin-Pharmacology, Types of Regimens, and Adjusment. San Fransisco: University of California.

Umpierrez G., Smiley D., Zisman A., Prieto LM., et al., 2007. Original Article: Randomized Study of Basal-Bolus Insulin Therapy in the Inpatient Management of Patient with Type 2 Diabetes (Rabbit 2 Trial). Diabetes Care. 30: 9, pp. 2181-2185

World Health Organization. 2016. Diabetes World Health Organization. Geneva: World Health Organization. 